\title{
Metaethical grounds for changing the understanding of values in Peter Singer's ethics (in the context of his reflection on the value of human life)
}

\author{
Jakub Synowiec \\ https://orcid.org/0000-0002-6357-6344
}

Following an analysis of Peter Singer's works the article reviews metaethical grounds for possible change of perception regarding social values. The author asserts that Singer applies the principle of equal consideration of interests as a tool to assess proposed changes in societal values. The novel point made in this paper is the observation that some changes in perceiving the values of human life and their implications arising from applying the principle of equal consideration of interests in ethical reflection conducted by the philosopher on the critical level of moral reasoning, cannot be promoted as principles on the intuitive level due to the application of the principle of equal consideration of interests on the metaethical level.

Keywords: Peter Singer, metaethics, value of life, principle of equal consideration of interests

Peter Singer is a deeply revisionist moral philosopher. He openly claims that his philosophy is aimed at changes in the realm of values and at rethinking specific views and attitudes that seem obvious to the contemporary man. Throughout his

JAKUB SYNOWIEC, PhD, Faculty of Philosophy, The Pontifical University of John Paul II in Cracow; address for correspondence: ul. Kanonicza 9/203, 31-002 Kraków, Poland; e-mail: jakub.synowiec@upjp2.edu.pl 
entire career Singer proposed many changes to and new understandings of different moral issues. It seems he was successful since he is considered to be one of the most influential living philosophers and his views on many ethical issues are perceivable in the public debate. His polemics against established views are interesting and still require more philosophical attention. This paper is an attempt to discover how and when, according to Singer, philosophers can change our understanding of values. Using Singer's work as an example, I will present his metaethical reflection and in order to present its application in a real and ethical argumentation, I will focus on one of his revolutionary views that is also fundamental to his ethical position - a change in our understanding of the value of human life.

Although philosophy tends to be seen as a purely academic discipline, Singer is fairly certain that it does actually change the world. The Australian philosopher has solid theoretical grounds for that statement, and elaborating on them will be the starting point of this article. In the next step, i.e. the principle of equal consideration of interests, which is a basis of Singer's ethics and his views that aim at remodeling the understanding the value of life, will be presented. In this section, the conclusions of Singer's ethical reflection will be briefly outlined. This is a necessary step to reconstruct the mechanism of selecting Singer's propositions for the changes necessary in understanding the realm of values. In the last section, the article will focus on the metaethical role that the principle of equal consideration of interests plays in Singer's ethics. It will also examine the resulting paradox, as it sometimes prevents the philosopher from popularizing conclusions which come from using this same principle in his professional work.

\section{Aim: Changing the World}

Peter Singer openly admits that, as a philosopher, he strives to transform the world into the best possible place. ${ }^{1}$ To attain this goal, he develops ideas that

\footnotetext{
${ }^{1}$ This approach is typical for utilitarian philosophers. It must be added though that Singer is a negative utilitarian, he prioritizes eliminating suffering over increasing overall happiness.
} 
change people's thinking and make them more moral ${ }^{2}$, indeed utilitarian. ${ }^{3}$ One of the obstacles in his way is traditional ethics, i.e. Christian ethics. From Singer's perspective, Christian ethics led to a crisis in morality and to unsolvable contradictions; therefore it is not an adequate ethical proposition ${ }^{4}$ as it does not lead to the best world possible. Actually, according to him, it is harmful.

Traditional ethics is a great obstacle because it is a basis for commonly accepted moral standards; the realm of values in Western societies was shaped on the basis of Christianity. Even in the most secular countries, traditional ethics can be found in attitudes and moral beliefs. It could be said that traditional ethics is still powerful in shaping the morality of contemporary man. ${ }^{5}$ For Singer, the problem is that the development of technology and medicine has caused a number of new moral problems, to which traditional ethics cannot be applied. Traditional ethics, with its rich and sophisticated theoretical level, is impossible to apply in practice. ${ }^{6}$ Therefore, according to Singer, it has collapsed and must be replaced, and our understanding of the realm of values must be subsequently changed ${ }^{7}$.

${ }^{2}$ Singer started reflection on this topic in his Master Thesis and developed it in a book Peter Singer, How are we to live? Ethics in an age of self-interest (Oxford-New York: Oxford University Press, 1997).

${ }^{3}$ For Singer, every moral person is at the same time, in principle, utilitarian. This view was developed and justified in his Practical Ethics (Cambridge: Cambridge University Press, 1999), 8-13.

${ }^{4}$ Peter Singer, Writings on an Ethical Life (New York: Ecco, 2000), XVIII.

${ }^{5} \mathrm{Cf}$. "Christianity has, for two thousand years, been a powerful influence on the moral intuitions of people in Western societies. People do not need to continue to hold religious beliefs to be under the influence of Christian moral teaching," Singer, Writings on an Ethical Life, XVIII.

${ }^{6}$ Singer believes the doctrine of the sanctity of human life is erroneous because it contains speciescist assumptions and because even Christian philosophers and theologians cannot coherently follow it, and when it comes to practice, not all human lives seem to have equal value. His favorite example is distinction of ordinary and extraordinary means which "is standardly used to justify withdrawing life support from, for example, a baby with ancephaly, or from an adult with no prospect of recovering consciousness" or the doctrine of a double effect. For a brief summary of his conflict with Christian philosophy on this issue see: Peter Singer, "Engaging with Christianity," in: God, the Good and Utilitarianism: perspectives on Peter Singer, ed. John Perry (Cambridge: Cambridge University Press, 2014), 58-61.

7 The collapse of the traditional ethics was announced in Singer's probably most controversial book: Rethinking Life and Death: The Collapse of Our Traditional Ethics (New York: St. Martin's Griffin, 1994). 


\section{Two Levels of Moral Thinking}

Singer claims that philosophers can change the world. ${ }^{8}$ This is also true for "the world of values" and especially for its perception. The philosophers' ability to change our world of values can be understood within the framework of the two levels of moral thinking, which was introduced by R. M. Hare. ${ }^{9}$ This famous distinction is also crucial for those who wish to understand Singer's ethics. According to Hare, our commonsense systems of values, moral norms, and the moral solutions we were taught by our parents, religion, or society which we feel comfortable to use belong to the intuitive level of moral thinking. Working on this level allows us to make quick, practical decisions concerning the moral sphere, and to spontaneously evaluate acts as good or bad. This comfortable level of moral thinking has one serious flaw: in some unexpected or untypical situations it stops working, it puts a person into unsolvable moral dilemmas, or it gives no clear answers as it does not cover the unanticipated situation. A moral subject may feel as if there is no right solution, whatever one does, and one cannot avoid feeling guilty. For Hare, a possibility of a moral conflict on the intuitive level reveals the higher level of moral thinking: the critical level. Reflection on this higher level "overrides" obedience to the simple rules present on the intuitive level, which are only prima facie rules.

On the critical level, it is possible to produce the right solution. Obligations cannot conflict and only one option is the best choice. ${ }^{10}$ At this level, one should analyze a moral situation carefully and without time pressures. Being on this level is difficult and requires appropriate skills, time, and knowledge of the moral situation, including expected consequences of the hypothetical actions that can be performed. Therefore, Hare recommends caution, but does not discourage using the critical level. In his metaethical reflection, Singer seems to go further: although all people are entitled to thinking about moral issues, most people, in typical cases,

\footnotetext{
${ }^{8}$ In one of his recent interviews, Singer admits: "Philosophy really changes people's lives, it changes what they eat or what they do with their time and money, sometimes it can even influence their career choice. Philosophy makes a great difference in our lives". Jakub Synowiec, "Mamy ze sobą coraz więcej wspólnego: Peter Singer i etyka chrześcijańska," [ We have more and more in common: Peter Singer and Christian ethics] an interview, in: Logos i Ethos 2016, no. 42: 189.

${ }^{9}$ Richard Mervyn Hare, Moral thinking: It's Levels, Method and Point (Oxford: Oxford University Press, 1981).

${ }^{10}$ Hare, Moral thinking: It's Levels, Method and Point, 25.
} 
even if they could potentially do more good by working on the critical level, should remain on the intuitive one and follow prima facie obligations, as in most cases this would have the best consequences. ${ }^{11}$ The critical level is not recommended for ordinary people in ordinary situations. Only moral experts should work on this level.

From the moral philosophers' point of view, Hare's division has one major advantage - it is a basis for them to feel useful and influential. Apparently, moral philosophers have the best predispositions to think on the critical level. They can be the best at taking the position of an impartial observer, as finding solutions to moral problems is what they are paid for. Consequently, they are professionals in the field of morality, especially when compared to random people who cope with moral problems only when they faced with them. In these situations they are probably influenced by time pressures, emotions, passions, or desires. What is more, moral philosophers were taught how to solve these problems; during their studies they acquired necessary skills and abilities. Finally, what might be the most important, experts in ethics have considerable time to deeply delve into moral problems. ${ }^{12}$ Hare believed that we should select principles of the intuitive level on the basis of reflection at the critical level. It appears that for Peter Singer, a moral philosopher (including himself) is an expert who looks carefully at prima facie principles (intuitive level), accepts them, refines them, and either rejects or creates new ones. If he is skilled or lucky enough to be influential, he can modify the common understanding of values.

${ }^{11}$ To illustrate it, Peter Singer uses bright metaphors, like the metaphor of the tennis player who could probably sometimes win by his untypical action, but most people would do worse if they did not follow the rules given by the coach. Listening to a good coach makes one more likely to succeed. A success in moral life is when one lives his life without doing wrongs in general (Singer presented this metaphor in the second edition of his Practical Ethics, 93-94). Cf. a metaphor of moral rules as recipes for inexperienced cooks, here Singer gently encourages to become an experienced chef who can "asses a recipe and decide how it should be improved". Singer, How Are We to Live?, 202-203.

${ }^{12}$ Singer presents this arguments in his very first paper Moral Experts and somewhat justifies his further struggles. Peter Singer, "Moral Experts," Analysis 32, no. 4 (1972): 115-117. Although Singer believes in the power of philosophy, he wanted to magnify his impact and became an activist (though for many not a sufficiently radical one; see: Singer, Writings on an Ethical Life, XX). 


\section{Principle of Equal Consideration of Interests}

If a moral philosopher can influence our understanding of values, then it is possible to change common moral views (intuitive level). And this is what Singer has struggled to achieve for his entire career. His most important book, Practical Ethics, starts with a critique of traditional ethics, which he identifies as Christian ethics $^{13}$. He aims at changing contemporary morality as he sees the weaknesses of the old doctrine and also notices the threat of the self-interest-oriented consumer life style, which dominates the most affluent societies. In this part of the article, the analysis of Peter Singer's metaethical reflection will be exemplified by his attempt to change our understanding of the value of human life.

To justify his ethical position, Singer needs to set the scene for thinking on the critical level. On the basis of a metaethical reflection on the nature of ethics he claims that the very basic moral intuitions lead every rational being to be committed to utilitarianism as the most minimalistic ethical approach. ${ }^{14}$ He himself claims to support preference utilitarianism ${ }^{15}$ with a fundamental rule: the principle of equal consideration of interests. The principle says that the like interests of different beings should have the same value in our moral considerations. ${ }^{16}$ To affirm this equality, a philosopher should try to take the position of an impartial observer. From this point of view, by considering a hypothetical action one can assess the interests of all beings affected by a certain action, without favoring a particular one, including oneself. Taking this position allows the individual to avoid discrimination because of gender, race, species, kin, or distance in space or time. If I can presume that my actions would affect some sentient creatures in the future, I should take it into the account of my moral considerations.

${ }^{13}$ Singer, Practical Ethics, $1-4$.

${ }^{14}$ Singer's argument is in: Practical Ethics, $10-14$. It has been criticized many times. It is analyzed in details by John Perry, who notices that "it is a suspiciously convenient story for utilitarians to find that all rational people are, by default, utilitarians" (John Perry, "Where did utilitarianism come from," in: God, Good and Utilitarianism, 31).

${ }^{15}$ Singer admits that there is an ongoing shift in his ethical thinking, due to confrontation with the moral views of Derek Parfit. Probably he is now less committed to preference utilitarianism than in those days when he wrote Practical Ethics, especially as regards satisfying irrational preferences. See: Peter Singer, "Engaging with Christianity," in: God, the Good and Utilitarianism, 65-67.

${ }^{16}$ Singer, Practical Ethics, 21. 


\section{Animals and People}

In traditional ethics, the assessment of the value of life of animals and the value of life of people differs. Working at the critical level, Singer uses the principle of equal consideration of interests to assess the prima facie rules as they are related to moral duties towards animals. Singer notices that animals have morally relevant interests and their most fundamental interests are very often neglected because of trivial human interests. For instance, an animal's interest to live or not to suffer is often thought to be outweighed by the human interest to have a varied menu. Singer calls the unjustified favoring the interests of humans over the interests of non-human animals "speciesism"17 and believes it is a serious error of contemporary moral thinking, which is comparable to racism or sexism. For Singer, prejudices against animals are deeply rooted in our culture, tradition, and even language. Therefore, it is difficult to overcome them. If we are to follow the principle of equal consideration of interests, we should never rank an animal's interests as lower than a human's like interests. A sum of the interests of a newborn human being is similar to a sum of interests of a dog, for example, because their mental capacities are similar. The isolated interest of a child to not feel pain is of the same value as the like interest of a horse. However, because a slap which is strong enough to put a child in pain would be barely noticed by a horse, slapping a child and a horse with the same strength requires a different moral assessment. ${ }^{18}$

Treating the interests of animals as equal with the like (isolated) interests of human beings is not the same as equating people with animals. Normally, adult people have increasingly more complex interests and their sum outweighs the sum of interests of animals. To emphasize this difference Singer distinguishes persons in the realm of moral subjects. For Singer, persons are rational and self-aware beings who are able to possess the most complex interests, including the interest to continue their lives. This characteristic is common to adult human beings. The Australian philosopher believes that not only people are persons, but some

\footnotetext{
${ }^{17}$ Ibidem, 55-62.

${ }^{18}$ Singer, Practical Ethics, 59.
} 
animals are rational and self-aware, too, thus, they are also persons. ${ }^{19}$ Lives of persons should be protected, although there is no "absolute" right to life in his ethical theory.

\section{People and Persons}

The thesis that some animals are persons might seem counterintuitive since (and Singer is aware) the term "person" is commonly used as an equivalent to "a representative of the species homo sapiens". Even more controversial is the idea that some people are not persons. Interestingly, Singer agrees with representatives of Christian ethics that a human being is a member of our species from conception on and there is no way to show that an embryo was "something else" before it became a human being. ${ }^{20}$ However, for him, being a member of a certain species is morally irrelevant. What matters are the interests, and members of our species start to have interests only sometime after conception (with the ability to feel pain). The number and complexity of interests depends on the level of development. In the earliest stages, an embryo has no interests When it becomes able to feel pain, Singer believes that this is an indicator that the act of killing it, though still permitted, should be as painless as possible. ${ }^{21}$ Furthermore, since the level of development does not change during birth, it cannot be the moment from which a child's life is protected. For Singer, just like many other moral philosophers holding traditional views, abortion at the late stage of pregnancy is morally equivalent to infanticide. Unlike them, he claims that, by virtue of that reasoning both can be justified in certain circumstances.

The principle of equal consideration of interests does not protect the lives of people whose rationality or self-awareness was destroyed by illness or damage to the body. People who are no longer rational and self-aware are not persons anymore. As they have no interest to continue their life, it is not protected on the basis of their interests. The value of their life is comparable to the value of the life of animals which are capable of having similar interests.

${ }^{19}$ See: Peter Singer, “Chimpanzees are People, too," in: Peter Singer, Ethics in The Real World (Princeton - Oxford: Princeton University Press, 2016), 64.

${ }^{20}$ Singer, Engaging with Christianity, 61.

${ }^{21}$ Singer, Practical Ethics, 151. 
The life of a given being, which is not a person, should be protected if it is protected by the preferences of a person. In this case, if the continuation of the life of a given being is in the interest of a person, these interests should also be taken into account in the moral deliberation. An embryo, even a disabled one, should be protected as long as the continuation of his/her life is one of the important interests of his/her parents.

In traditional ethics, the life of every human has equal, intrinsic, and very high value. It should always be protected. Singer rejects this thinking as erroneous and claims that the value of human life is related to the level of development of a given individual, and for a long period of his/her life, it is not higher than the value of life of some animals. After years of his reflection on the critical level ${ }^{22}$, he aims at changing our understanding of the value of human life and proposes new prima facie obligations which became "famous" as "Singers Five Commandments": "recognize that the worth of human life varies" 23 - which means people should be treated according to their morally relevant characteristics; "take responsibility for the consequences of your decision"24 - euthanasia is allowed but doctors must be sure they do the right thing; "respect persons' desire to live or die"25 - this rule protects persons from being killed against their preferences and allows them to choose death if it is according the their preferences; "bring children into the world only if they are wanted"26 - unwanted children can be aborted; "do not discriminate on the basis of species" 27 - consider the interests of non-human beings the way they deserve it from the point of view of an impartial observer. $\mathrm{He}$

${ }^{22}$ Singer analysed the topic for many years in a number of books and articles, apart from the already mentioned Practical Ethics and Rethinking of life and death, it is worth familiarizing oneself with his co-authored books: Peter Singer, Helga Kuhse, Stephen Buckle, Karen Dawson, Pascal Kasimba, Embryo Experimentation. Ethical, Legal and Social Issues (New York: Cambridge University Press, 1993); Peter Singer, Helga Kuhse, Should the Baby Live? The Problem of Handicapped Infants (Oxford: Oxford University Press, 1985) or the article whose title summarizes the shift in understanding the value of human life that Singer would like to create: Peter Singer, "Sanctity of Life or Quality of Life?" Pediatrics 72, no. 1 (1983): 128-129.

${ }^{23}$ Singer, Rethinking life and death, 190.

${ }^{24}$ Ibidem, 194.

${ }^{25}$ Ibidem, 197.

${ }^{26}$ Ibidem, 200.

${ }^{27}$ Ibidem, 202. 
also encourages acceptance of the belief that parents have a right to decide whether or not an infant should continue to live. ${ }^{28}$

Singer's bioethical views are well known. They continue to be controversial and have been criticized many times, both as such and because they are based on a naturalistic anthropology. On the other hand, Singer is still an influential thinker and openly claims that his objective is to alter intuitive morality. As a philosopher, he has the right to do that, and, if he is wrong on the critical level, it should be proved. This is what every philosopher can expect from their fellow-philosophers.

\section{Indirect Killing - Duties to the Poor}

The alternative understanding of the value of life which is postulated by Peter Singer on the critical level, on the basis of the principle of equal consideration of interests, has one more implication which is quite controversial but has not received much public attention until recently. If the interests of other persons are to be treated as equal to one's identical interests, then it is a moral obligation to resign from one's trivial interests in order to satisfy the more important interests of others. Singer illustrates it in his famous metaphor of the pond. ${ }^{29}$ We can imagine a pond in which a small child is drowning. His/her interest to live is seriously threatened. One can save the child, but at the risk of ruining one's shoes. Even if the shoes were exceptionally rare and expensive, people tend to agree that not saving a child in these circumstances counts as a moral evil. Therefore, one ought to save the child. How grave this evil is depends on the views of indirect killing. Singer is a philosopher who takes it very seriously. ${ }^{30}$ Since both acting and restraining from action have consequences, people are similarly responsible for killing and letting die. For that reason, letting the child in the pond die is nearly morally equivalent to murdering the child. ${ }^{31}$ For Singer, each of us is in the shoes of

\footnotetext{
${ }^{28}$ Ibidem, 210-212.

${ }^{29}$ The most developed version of this argument can be found in: Peter Singer, The Life You Can Save (London: Picador, 2009), 3-4 and 15-19.

${ }^{30}$ L.S. Cahill argues that "not all who defend the sanctity of innocent life as absolute take with comparable moral seriousness the "indirect" killing of millions by poverty, war and preventable disease", Lisa Sowle Cahill, "Moral reason, community belonging, and global justice," in: God, The Good and Utilitarianism, 109.

${ }^{31}$ Singer, Practical Ethics, 222-229.
} 
the person who encounters a drowning child in a shallow pond. There are many people in the world whose basic interests are threatened (they are likely to die due to hunger, easily preventable diseases, and so on) and to save them we are supposed to sacrifice something of small importance, especially if we live in the most affluent societies. For rich contemporary people, effective help to those in extreme need was made easy by the same technology that allows them to live in incredible affluence, as it requires only a few clicks to complete a money transfer to a recommended charity. ${ }^{32}$ For Singer, affluent people have a moral duty to abandon their trivial interests for the sake of the fundamental interests of people living in extreme poverty, even if they will not ever meet them. So much extends from the principle of equal consideration of interests: We can affect these people by our actions. Therefore, we should, in our moral considerations, regard their interests as equal to our own.

Working on the critical level, a moral philosopher can tell us precisely which interests should be abandoned in this case, namely: what is nearly as important as the life of another person? Singer writes explicitly that if one has safe water in his tap, one should not buy bottled water - it is an unnecessary expense..$^{33}$ Any consumer decision can be seen from the perspective of an impartial observer calculating the interests of everyone affected. From this point of view, one should also consider whether the limited resources he has would not be better used elsewhere; maybe a certain good to be obtained can be of lower quality and still serve its purpose and the money saved could be donated, e.g. to fighting global poverty. We can examine the decision to buy a car through the means of this framework. The market for luxury cars is considerable and growing, yet, rationally thinking, cheaper cars serve poorer people well enough and the majority of people do not need premium vehicles. Imagine one who can afford a luxury car but, influenced by Singer's remarks and the principle of equal consideration of interests, understands it is his duty to include the interests of others in his calculation. Therefore, he or she would understand that if they need a car at all, it should be a car that is

\footnotetext{
${ }^{32}$ Singer has always been very much attracted to the idea that a choice of a right charity organization is a very important factor of our giving. In The Life You Can Save he gave his own recommendations (see: 82-104) but in his most recent book Peter Singer, The Most Good You Can Do (New Haven and London: Yale University Press, 2015), 149-164, he advises following recommendations of a movement called "Effective Altruism" for which he is a source of inspiration, intellectual support and also a founder.
}

${ }^{33}$ Singer, The Life You Can Save, IX. 
sufficient to satisfy his real needs, not the best one they can afford - and the rest of the money should be spent in a way that would bring the most good, namely: donated to the most effective charities. We can imagine many areas where similar savings could be achieved - how far should we limit ourselves for the sake of the crucial interests of others whom we cannot identify, let alone hug or shake hands with $?^{34}$ For Singer, from the impartial point of view, we should give until we reach the level on which it would be expected of us to give something that is of the same equivalent moral value to life, so probably we are supposed to reach the level of marginal utility. ${ }^{35}$ Thinking on the critical level allowed Singer to understand that the value of life of other persons (not people!), even those unknown to us, is so high that a radical change in the lifestyle of the ordinary citizen of an affluent country should take place.

\section{Utilitarianism is too demanding?}

Although on the critical level the Australian philosopher could not find a flaw in his argument of the duty to give away everything that has a value lower than the value of life, he does not popularize this "objective standard" as a prima facie obligation. A thesis of this paper is that on the metaethical level Singer applies the principle of equal consideration of interests to his professional work. After all, the work of a moral philosopher is also the type of action which can be evaluated as right or wrong. It influences some sentient beings, so the ways one can do it may bring different outcomes concerning maximizing interests. One can hold the traditional view that ethics should reveal the truth about what is right or wrong, and that it is the task, or even the vocation, of a moral philosopher to deliver conclusions of his reflection on the critical level to society and so try to alter people's thinking on the intuitive level of moral reasoning. It appears that the metaethical views of Singer are a challenge to the traditional view of the role of the

${ }^{34}$ Many people inspired by Singer's thought ask this questions, sometimes going into a radical direction. Some of them think about not having children, as the equivalent of the cost of raising a child can be donated to the most effective charity to save many lives and having a child is not necessary (Singer, The Most Good You Can Do, 29-31); others decided to donate one of the "double" organs (67-68).

${ }^{35}$ Singer, The Life You Can Save, 18. Practical Ethics, 231-232. 
moral philosopher. Sometimes it is right to avoid presenting views that are conclusions reached on the critical level, as this leads to better consequences in terms of respecting the principle of equal consideration of interests.

The Australian philosopher does not present his metaethical views in detail, but they can be reconstructed on the basis of his ethical argumentation. In the case of the duty of abandoning trivial interests for the sake of the crucial interests of unknown others, he admits that this standard might simply be too demanding. ${ }^{36}$ Resigning from the luxurious and comfortable life of a member of affluent society for the sake of saving the lives of random people in Africa may be perceived as a type of heroism. Claiming it to be the moral duty of every person would cause a rejection of Singer's ethics, rather than changing the attitudes of citizens of our societies. ${ }^{37}$ In this case, what is the best thing to do is not what moral philosophers should advocate and not what they should try to put in the set of prima facie principles.

From this reasoning, it appears that as a philosopher Singer uses the principle of equal consideration of interests also on the meta-level of his moral reasoning. If we consider the career of a moral philosopher from the perspective of an impartial observer, we can assume that he or she should promote those solutions that would bring the best consequences (satisfying the most interests). It seems unlikely to convince masses to take the impartial point of view and donate everything beyond the necessities to the most effective charities, but it is still possible to make people more generous, as Singers argues, to avoid the risk of a counterproductive ethical argumentation "we should advocate a level of giving that will lead to a positive response. Because I want to see those in poverty receive as much as possible of the aid they need, I think we should advocate a level of giving that will raise the largest possible total, and so we have the best consequences". ${ }^{38}$ For that reason, Singer accepts a less demanding standard, which can be accepted by many - an obligation to help by giving a part of one's income ( $10 \%$ or so) - so that an affluent person would not feel it as a sacrifice, and yet it would still be satisfactory given

${ }^{36}$ Singer, Practical Ethics, 246.

${ }^{37}$ See, for example: Collin McGinn, "Our duties to animals and the poor" In: Singer and his critics, ed. Dale Jamieson (Oxford: Blackwell, 1999), 154-159 or Gordon Preece, "The Unthinkable and Unlivable Singer," in: Rethinking Peter Singer. A Christian Critique, ed. Gordon Preece (Downers Groove: Intervarsity Press, 2002), 35.

${ }^{38}$ Singer, The Life You Can Save, 151-152. 
the number of saved people. ${ }^{39}$ An affluent person can become a superhero without changing their lifestyle or even leaving their room - only a few clicks are necessary. Singer encourages the changing of our career paths or work patterns in order to earn even more for moral reasons - namely, to increase the amount of money one can donate: a rich person can easily save even hundreds of people during his entire career. ${ }^{40}$ Singer wants to change prima facie obligations regarding our duties to the poor but not in a radical way, which is the logical conclusion of his ethical reflection. However, if one thinks about his or her moral duties on the critical level, one may still discover the real value of life of all those people one can save and take the more demanding standard of giving.

\section{Conclusion}

A moral philosopher, while working on the critical level, may change the prima facie obligations of the people whom he/she can influence as an expert. As a consequentialist moral philosopher, he or she should even feel obliged to influence the values of people in the direction of his or her ethics.

Peter Singer has proved that he is able to do so. Effective altruism is a proof that, for many individuals, the life of people in distant countries, or even in the distant future, has great value.. In many countries, Singer's arguments on abortion or euthanasia resonate in public debates about changes in law. Although Singer does not always popularize the most radical conclusions of his ethics, the prima facie rules he proposes appear to make a substantial change in his followers' perception of the value of human life, in comparison to the view of supporters of traditional ethics.

The thesis of this article is that Singer supplements Hare's view on creating/modifying rules on the intuitive level of moral reasoning by applying, at the critical level, the principle of equal consideration of interests. This principle guides his professional activity as a philosopher in proposing certain prima facie principles that should be followed in everyday life. We have seen that the principle of equal consideration of interests plays at least two roles in Peter Singer's ethics.

\footnotetext{
${ }^{39}$ Singer, The Most Good You Can Do, 97-98.

${ }^{40}$ Ibidem, 39-44.
} 
It is the basic principle on the basis of which Singer, as a professional and influential thinker, attempts to analyze, modify, confirm, or reject current prima facie obligations, as well as to create new ones, which are necessary for contemporary man as he faces the moral challenges of our times. Another, and maybe even more prominent, role of this principle is its control over Singer's professional activity. Applying it on the metaethical level makes the philosopher propose a set of rules and values on the intuitive level - only those that would lead to the best expected consequences (in terms of maximizing interests). As we have worked to present in this paper, the principle of equal consideration of interests applied on the metaethical level may sometimes be against popularizing views that are the outcome of this principle. Advocating this outcome could possibly bring adverse consequences, when compared to advocating a less demanding standard. From the perspective of a consequentialist ethics, this does not seem to be an error in thinking. Rather, it proves that a moral philosopher subjects himself to the ethics he is advocating.

In a sense, we are lucky Peter Singer did not apply the principle of equal consideration of interests into his career before he started it, which he now advises young people to $\mathrm{do}^{41}$. How likely is it that a good student would become a prominent moral philosopher with an ability to influence many people? Even Peter Singer claims he was rather lucky to became famous and influential. ${ }^{42}$ Philosophy does not seem to be the best path if one is motivated by Singer's ethics and decides to evaluate his future career considering the principle of equal consideration of interests. If Peter Singer had known this conclusion of his ethics, he would not have had a chance to develop it. This paradox tells us something important about our ability to predict which actions will maximize interests.

\section{Bibliography}

Cahill, Lisa Sowle. "Moral reason, community belonging, and global justice.” In: God, the Good and Utilitarianism: perspectives on Peter Singer, ed. Perry John, 104-124. Cambridge: Cambridge University Press, 2014.

\footnotetext{
${ }^{41}$ See: Singer, The Most Good You Can Do, 39-65.

${ }^{42}$ Singer emphasizes it in many of his interviews, when asked about his successful career. See for example: Shawn Young, Interview: Peter Singer, https://www.shawnyoung.com/interviews/petersinger.php (access: 27.08.18).
} 
Pobrane z czasopisma http://kulturaiwartosci.journals.umes.pl

Hare, Richard Mervyn. Moral thinking: It's Levels, Method and Point. Oxford: Oxford University Press, 1981.

McGinn, Collin, "Our duties to animals and the poor." In: Singer and his critics, ed. Dale Jamieson, 150-161. Oxford: Blackwell, 1999.

Perry, John. "Where did utilitarianism come from." In: God, the Good and Utilitarianism: perspectives on Peter Singer, ed. John Perry, 15-52. Cambridge: Cambridge University Press, 2014.

Preece, Gordon. “The Unthinkable and Unlivable Singer.” In: Rethinking Peter Singer. A Christian Critique, ed. Gordon Preece, 23-67. Downers Groove: Intervarsity Press, 2002.

Singer, Peter, "Chimpanzees are People, too." In: Ethics in The Real World, ed. Peter Singer, 63-65. Princeton - Oxford: Princeton University Pres, 2016.

Singer, Peter, Helga Kuhse, Stephen Buckle, Karen Dawson, Pascal Kasimba. Embryo Experimentation. Ethical, Legal and Social Issues. New York: Cambridge University Press, 1993.

Singer, Peter. Engaging with Christianity. In: God, the Good and Utilitarianism: perspectives on Peter Singer, ed. John Perry, 53-67. Cambridge: Cambridge University Press, 2014.

Singer, Peter. How are we to live? Ethics in an age of self-interest. Oxford-New York: Oxford University Press, 1997.

Singer, Peter. “Moral Experts.” Analysis 32, no. 4 (1972): 115-117.

Singer, Peter. Practical Ethics. Cambridge: Cambridge University Press, 1999.

Singer, Peter. Rethinking Life and Death: The Collapse of Our Traditional Ethics. New York: St. Martin's Griffin, 1994.

Singer, Peter. “Sanctity of Life or Quality of Life?” Pediatrics 72, no. 1 (1983): 128-129.

Singer, Peter, Helga Kuhse. Should the Baby Live? The Problem of Handicapped Infants. Oxford: Oxford University Press, 1985.

Singer, Peter. The Life You Can Save. London: Picador, 2009.

Singer, Peter. The Most Good You Can Do. New Haven and London: Yale University Press, 2015.

Singer, Peter. Writings on an Ethical Life. New York: The Ecco Press, 2000.

Synowiec, Jakub. "Mamy ze sobą coraz więcej wspólnego: Peter Singer i etyka chrześcijańska," [ We have more and more in common: Peter Singer and Christian ethics] an interview. In: Logos i Ethos 2016, no. 42: 155-175.

Young, Shawn. Interview: Peter Singer, https://www.shawnyoung.com/interviews/peter-si Accessed 24.08.2018. 
Pobrane z czasopisma http://kulturaiwartosci.journals.umes.pl

Jakub Synowiec, Metaethical grounds for changing the understanding of values...

\section{Streszczenie}

Metaetyczne podstawy zmiany rozumienia wartości w etyce Petera Singera (w kontekście jego rozważań o wartości życia ludzkiego)

Artykuł przedstawia metaetyczne podstawy dla możliwości zmiany społecznego postrzegania wartości, w oparciu o analizę prac Petera Singera. Tezą artykułu jest, że Singer stosuje zasadę równego rozważania interesów jako narzędzie oceny proponowanych zmian w wartościach społecznych. Nowatorskim akcentem artykułu jest dostrzeżenie, że niektóre zmiany $\mathrm{w}$ rozumieniu wartości życia ludzkiego oraz ich implikacje wynikające z zastosowania zasady równego rozważania interesów w refleksji etycznej, prowadzonej przez filozofa na krytycznym poziomie rozumowania moralnego, nie mogą być popularyzowane jako zasady ma poziomie intuicyjnym, ze względu na zastosowanie zasady równego rozważania interesów na poziomie metaetycznym.

Słowa kluczowe: Peter Singer, metaetyka, wartość życia, zasada równego rozważania interesów

\section{Zusammenfassung}

Metaethische Grundlagen des Wandels im Verständnis der Werte in der Ethik von Peter Singer

(im Zusammenhang seiner Überlegungen vom Wert des menschlichen Lebens)

Der Artikel präsentiert metaethische Grundlagen für die Möglichkeit, die soziale Wahrnehmung der Werte in Anlehnung an die Analyse der Schriften von Peter Singer zu verändern. Es wird die These aufgestellt, dass Singer das Prinzip der Interessenabwägung als das Beurteilungsinstrument der vorgeschlagenen Veränderungen in den sozialen Werten anwendet. Einen innovativen Akzent des Artikels stellt die Bemerkung dar, dass einige Veränderungen im Verständnis des Wertes des menschlichen Lebens und ihre Implikationen, die aus der Anwendung des Prinzips der gleichen Interessenabwägung in der ethischen Reflexion (die vom Philosophen auf einem kritischen Niveau der moralischen Schlussfolgerung geführt wird) resultieren, nicht als Prinzipien auf intuitivem Niveau verbreitet werden können, wegen der Anwendung des Prinzips der gleichen Interessenabwägung auf metaethischem Niveau.

Schlüsselworte: Peter Singer, Metaethik, Wert des Lebens, Prinzip der gleichen Interessenabwägung 
Informacja o Autorze:

JAKUB SYNOWIEC, dr, Wydział Filozoficzny, Uniwersytet Papieski Jana Pawła II w Krakowie; adres do korespondencji: ul. Kanonicza 9/203, 31-002 Kraków; e-mail: jakub.synowiec@upjp2.edu.pl

\section{(cc) EY-NG-ND}

